\title{
Supraglottic Cancer pTis TNM Finding v8
}

National Cancer Institute

\section{Source}

National Cancer Institute. Supraglottic Cancer pT is TNM Finding v8. NCI Thesaurus.

Code C133101.

Suprag lottic cancer with a finding of carcinoma in situ. (from AJCC 8th Ed.) 